\title{
Beyond Mere Containment: The Neapolitan Treasury Chapel of San Gennaro and the Matter of Materials
}

\author{
Helen Hills
}

The grand and imposing Treasury Chapel, which truly can be called a treasure, both for what is kept there, and for what was spent on it. ${ }^{1}$

What are we to make of the Treasury Chapel of San Gennaro in Naples cathedral (Figs. 1-2)? Built and decorated largely between 1608 and 1770, it is the place where the miraculously liquefying blood of San Gennaro, Naples' principal patron saint, is kept and was also the principal site of its liquefaction. The Treasury Chapel housed relics of Naples' many protector saints of which there were as many as thirty-two by 1731, far more than anywhere else in Europe and probably more than anywhere else in the world. At the heart of the chapel was the miraculous blood of San Gennaro (Saint Januarius), Bishop of Benevento, beheaded as a Christian in 305 in Pozzuoli. An ampule of his blood, presciently gathered by a pious Neapolitan woman, when brought into contact with his head relic either miraculously liquefies to indicate that all is well, or fails to do so, auguring calamity. In either case, the sign is interpreted as an affirmation of San Gennaro's heavenly intercession to protect Naples.

We enter via the aisles of the cathedral, through the vast subdued architectural frame of the majestic bronze gate and suddenly the chapel presents itself to our gaze (Fig. 3).

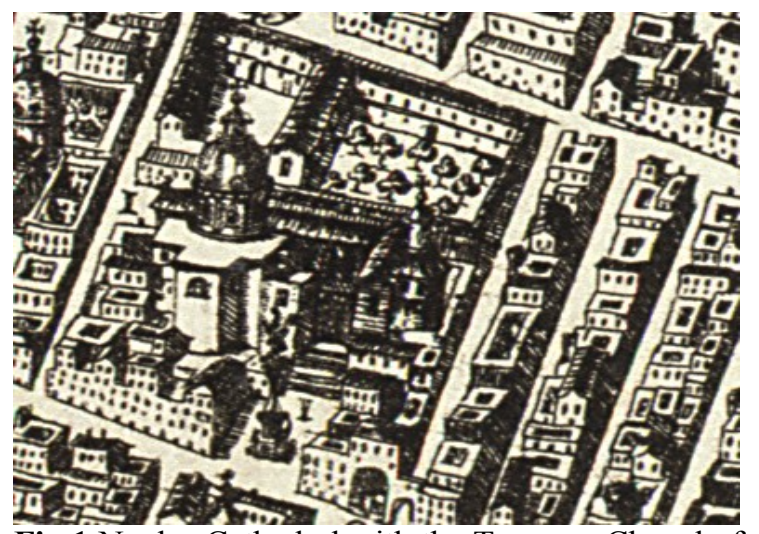

Fig 1 Naples Cathedral with the Treasury Chapel of San Gennaro. Detail from Paolo Petrini, Pianta ed alzata della città di Napoli (Naples, 1718). BL Shelfmark: 24045(29) \& BLL01004895786.

$1 *$ An earlier version of this paper was given at 'The Arts and Sciences in Seventeenth- and Eighteenth-Century Naples: Discovering the Past, Inventing the Future' at The UCLA Center for Seventeenth- \& Eighteenth-Century Studies at The William Andrews Clark Memorial Library in 2010. I should like to thank John Marino and Margaret Murata in particular for their encouragement and inspiring conversations. I am also grateful to anonymous readers for their suggestions. Research for the article was made possible by an AHRC Matching Leave research grant and a British Academy Research Readership. I warmly thank those institutions for their invaluable material support. My grateful thanks also to Rossella Carbotti for her kind assistance.

.Carlo Celano, "La grande e maestosa cappella del Tesoro; che veramente dir si può tesoro, e per quello che vi conserva, e per quello che speso fu," in Notizie del Bello dell'Antico e del Curioso della Città di Napoli, ed. Giovanni Battista Chiarini (Naples: Agostino di Pascale, 1858), vol.3 pt.1, 235. 


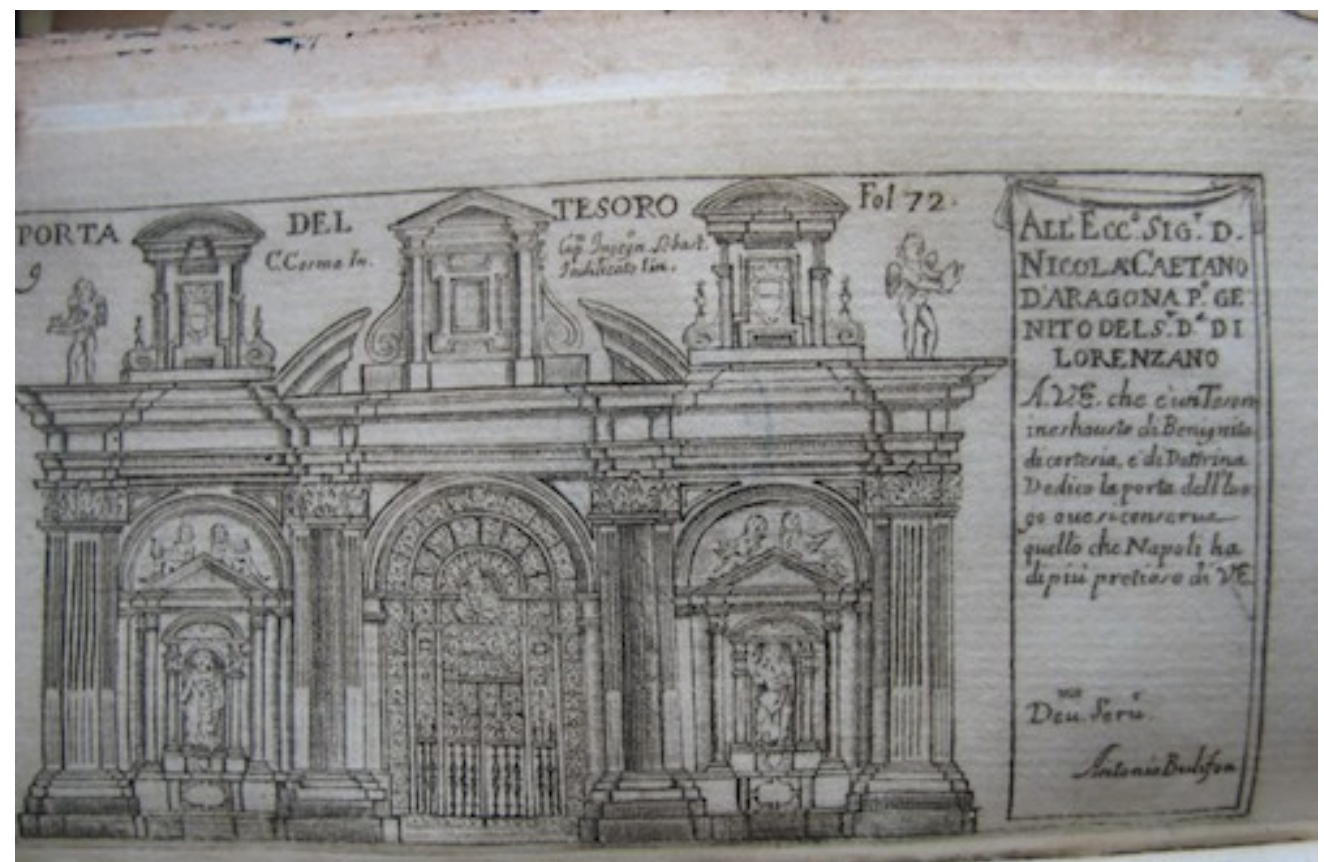

Fig 2 Pompeo Sarnelli, Guida de Forastieri, Curiosi di vedere, e d'intendere le cose più' notabili della Regal Città di Napoli, e del suo amenissimo Distretto, Naples: Giuseppe Roselli, 1697. The Treasury Chapel of San Gennaro from the southern aisle of the cathedral. By permission of the Biblioteca Nazionale di Napoli.

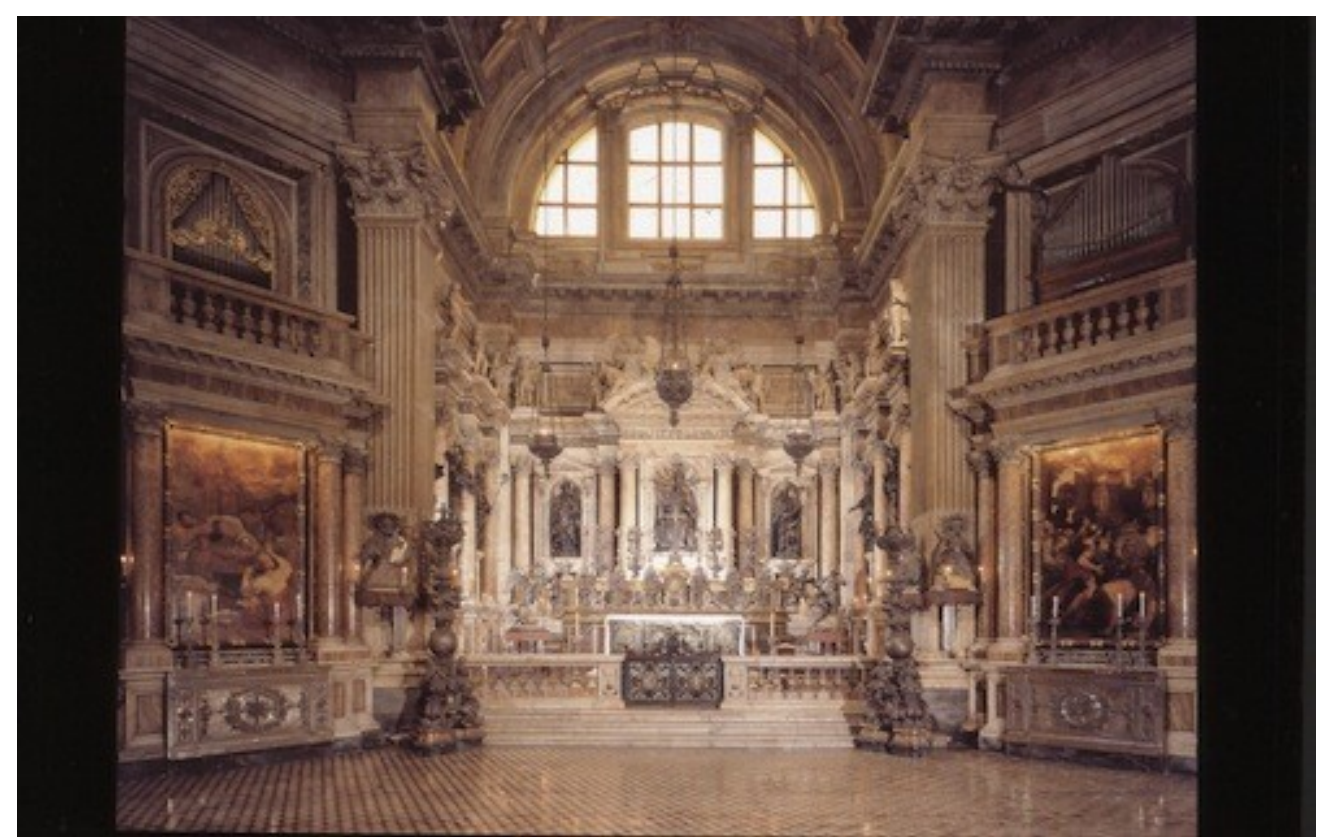

Fig. 3 Treasury Chapel of San Gennaro, Naples. Interior view looking towards the main altar.] Photo (C) Helen Hills. By kind permission of the Eccellentissima Deputazione della Reale Cappella del Tesoro di San Gennaro.

It is overwhelming: an explosion of glittering surfaces and colour, a space as large as a church, crowned with a soaring cupola, dazzlingly frescoed, a space where polished coloured marbles seem to tilt with glittering metal, while dark self-absorbed bronze figures brood in recesses and silver saints shimmer in every available crevice (Fig. 4). 


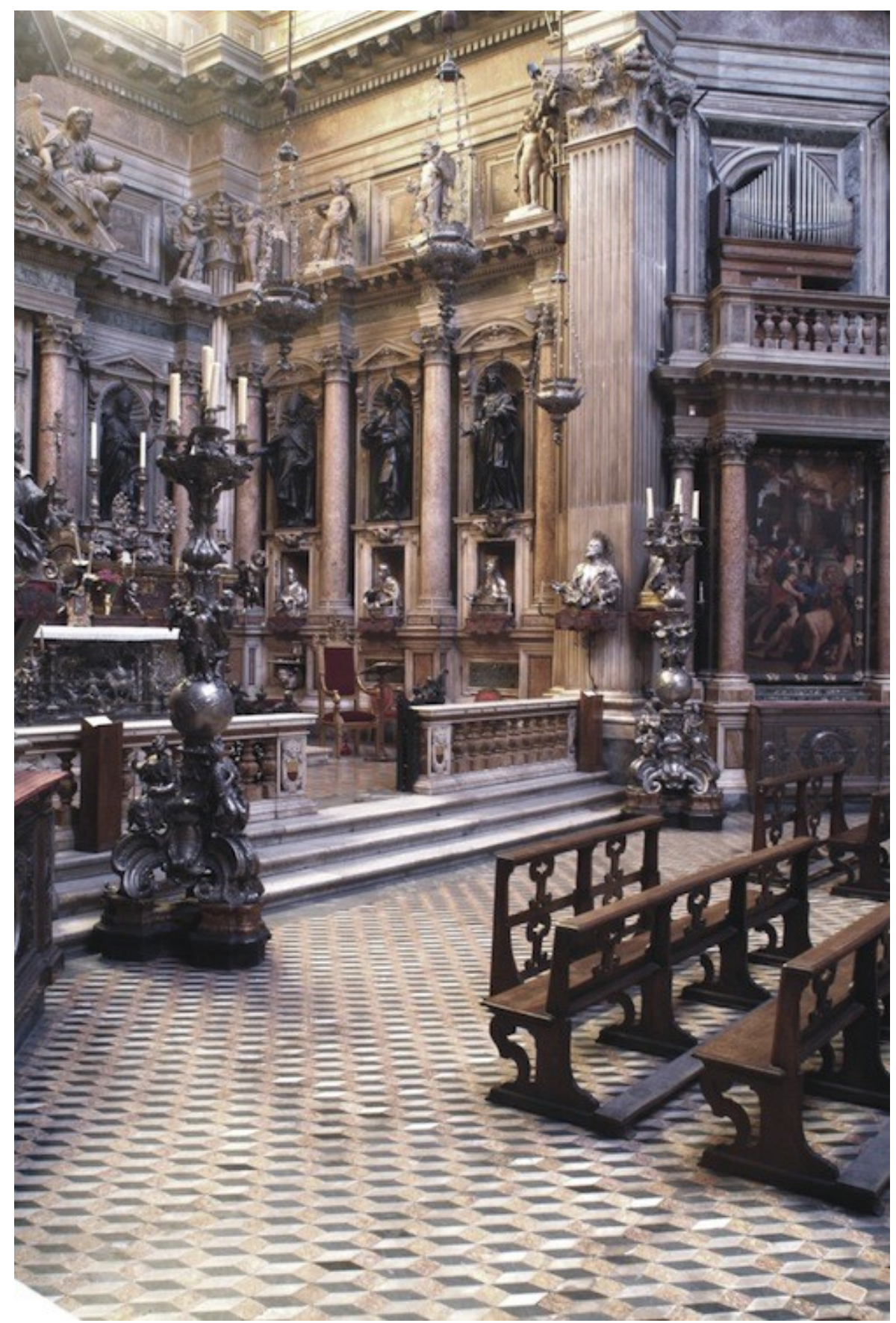

Fig 4 Naples, Treasury Chapel of San Gennaro. Dark self-absorbed bronze sculptures. Photo (C) Helen Hills. By kind permission of the Eccellentissima Deputazione della Reale Cappella del Tesoro di San Gennaro.

Here are intertwinings, a refusal of a coherent sense of direction or reading: a proliferation that implicates the viewer. Porphyry altar, bronze gateways, marbled walls, altarpieces, precious metals, and semi-precious stones brandish colour and polished surface in intense competition for attention in a flickering unstable light. Luminosity (lumen) is pitched directly against shadowed recess; light (lux) against dark. Everywhere one looks, there is an abundance of luxuriant, exuberant claims, from the dome, splashed with light, to the shadowy presbytery populated by busts and statues peering from darkened niches to the vast glittering silver candlesticks and the smooth subtle grey and parchment white geometric pavement. What is to many visitors of Protestant sensibilities dismissively characterised as "excessive" 
or "over the top" seems to pull the visitor in all directions at once. Below I briefly trace the principal shortcomings of an historicist approach in light of the emotional and material demands the chapel makes, before articulating an approach to the chapel that allows it to be more than mere passive container for extravagant materials, but active and productive; and I suggest that the chapel can usefully be read as a machine for producing protector saints.

The chapel is a multiple deployment of surfaces, colors, textures, making possible not one or two univocal significations, but entire constellations of meanings. Material richness, surface sheen, and formal and iconographical complexity engulf us. ${ }^{2}$ No wonder, then, that art historians have tended to respond to the Treasury Chapel by trying to produce order out of its apparent chaos. Dates and names; a chronological string; a linear history on which to hang this overwhelming richness; to string it out in narrative clarity, to order and delimit what evades boundaries and reins. There has been an apparently irresistible urge to name, identify, to date and to chronologize, with regards to the architecture, paintings, reliquary busts and statues. ${ }^{3}$ As if the naming and identifying, the dating, listing, and ordering were to perform the history of art. Site is thereby reinvested with the desire for continuity in an anxious historicist impulse. But historicism works to abandon the historical object by equating it with its literal presence and by suspending contingency and discontinuities in favor of narrative coherence, guided by a notion of time as progressive, if only in the sense of linearity and continuity. Thus the Treasury Chapel has been reduced most readily to the context of the so-called "CounterReformation," even while the part it plays in the miraculous liquefaction is sidestepped. ${ }^{4}$

There is, however, no good reason to treat the chapel as if its "context" necessarily limits how it might be interpreted or what it can do. Arguably, the chapel transformed its context, transformed the very context of architecture and expressed the power of difference that would open up new contexts. To interpret the chapel within the constraints of a preexisting notion of the "Counter-Reformation" is to fail to engage with the potential of both the chapel and of the complexity of impulses constituting what might (post hoc) be termed "Catholic reform." I want to insist there is no architecture in itself. Its status and effects have varied according to radical changes of technology and beliefs. Neither architecture nor religion existed in the first place: to consider aspects of the chapel as material analogy for the

2 This is not at all to imply, as an anonymous reader has suggested, that the chapel is best interpreted in terms of style. Indeed, the chapel has often been presented as a masterpiece of "Counter-Reformation," "late Renaissance," and even as "early Baroque (or proto-Baroque) architecture." Such characterizations are not part of this project. The same reader suggests that a sensible approach would be to date each artwork and part of the chapel to indicate their "chronological order." This has indeed already been done by Bellucci and other scholars. My point is precisely that such concern with chronicity is to replace an interpretation of the orchestration with a dating and naming of parts. For chronologizations, see Antonio Bellucci, Memorie storiche ed artistiche del tesoro nella Cattedrale: dal secolo $16^{\circ}$ al $18^{\circ}$ desunte da soli documenti inediti (Naples: Antonio Iacuelli, 1915); Franco Strazzullo, La Real Cappella del Tesoro di S. Gennaro. Documenti inediti (Naples: Società Editrice Napoletana, 1978); Idem, La Cappella di San Gennaro nel Duomo di Napoli (Naples: Istituto Grafico Editoriale Italiano, 1994); Elio Catello and Corrado Catello, La Cappella del Tesoro di San Gennaro (Naples: Edizione del Banco di Napoli, 1977).

3 See Bellucci, Memorie storiche ed artistiche del Tesoro; Strazzullo, La Real Cappella del Tesoro di S. Gennaro, 1978; Idem, La Real Cappella del Tesoro di San Gennaro. Documenti inediti, (Naples: Società Editrice Napoletana, 1978); Idem, La Cappella di San Gennaro nel Duomo di Napoli (Naples: Istituto Grafico Editorial Italiano, 1994); Elio Catello and Corrado Catello, La Cappella del Tesoro di San Gennaro (Naples: Edizione del Banco di Napoli, 1977); Elio Catello, "Argenti Napoletani del Seicento: considerazioni su documenti inediti," in Ricerche sul '600 napoletano (1998): 7-15; Silvana Savarese, Francesco Grimaldi e l'architettura della Controriforma a Napoli (Rome: Officina Edizioni, 1986); Idem, "Francesco Grimaldi e la transizione al Barocco. Una rilettura della Cappella del Tesoro nel Duomo di Napoli," in Barocco Napoletano, ed. Gaetana Cantone (Rome: Istituto Poligrafico e Zecca dello Stato Libreria dello Stato 1992), 115-136; Vincenzo Cerino, San Gennaro: Un Santo, un Voto e una Cappella (Naples: Rolando Editore, 2005).

4 This is the established mode of interpretation of the chapel and is most starkly articulated in Savarese, Francesco Grimaldi, 116-126. 
miraculous liquefaction of San Gennaro's blood is my concern here. ${ }^{5}$ This is not to claim that architecture has a concealed belief or meaning behind it. There is no autonomous "base" or "origin" "outside" of architecture which can serve to "explain" it, and which architecture seeks to "represent," to house, to embody (or exclude). ${ }^{10}$ Architecture is not merely representation of ecclesiastical impulse, nor expression of meaning, but the invention of ambition, the production of sense, allowing new perceptions and new worlds.

This essay is therefore a consideration of the problems encountered in attempting an art historical analysis of the complex forms of a work of Neapolitan baroque architecture, when confronted on the one hand by the rather bald, roughly contemporaneous accounts thereof and, on the other and more especially, by the thrilling experience of entering these buildings today - experiences that leave one overwhelmed and at a loss: at a loss for words sufficient to them and at a loss in their regard. To look at these buildings today in terms of their affective material productivity, even if they can only be articulated incompletely, is to ask historians to undertake the kind of visual work to which they are seldom accustomed. ${ }^{6}$ It means staying the customary hastiness that treats architecture as mere instantiation of idea, and instead - while resisting the temptation to interpret architecture as merely the sum of its parts - requires a willingness to inquire into the materiality of aspects of architecture and objects which resist representational interpretation, and which yield 'nothing' to see (such as dark areas within sculpture, non-figurative passages within architecture, the shine of silver, illegible letters of unknowable alphabets). Simultaneously, we need also to widen our usual scope of vision to restore to architecture its affective elements that make it work. It is therefore to require the mobility of the work of architecture (its demands) to engage us fully and temporally, rather than to desiccate architecture into a "document" of a "social," "political," "cultural," "sensational," "affective," or "material" history, imagined as preceding the chapel, supposedly capable of explaining it and of embracing it fully, but to which it is, in fact, subordinated. This is absolutely not to suggest that we dispense with "reason" in favor of affect; nor is it to advocate engaging with the "senses" as if they operate separately from thought, conceptualization, the imagination, or history. It is to resist the notion that architecture is mere representation (including a representation of phenomenological effect or of sensory affect). Instead of treating architecture as a representation of a pre-existing reality, we need to think history politically in its fullest sense. And it is here that resistance usually arises.? As Georges Didi-Huberman has expressed it, "the motionless truth that merely keeps the researcher waiting does not correspond in any way to the concept of truth in the subject of history [...]: it is another, unique and irreplaceable image of the past that fades with each present that has failed to recognize itself as its aim."”

Thus, I consider the problems posed by prevailing historicist approaches to this challenge, while seeking to delineate an interpretation that is materialist, historical, and

5 Limits on space require a focused argument here, but it could readily be extended to embrace further aspects of this chapel.

6 For rich and important discussions of materials and their potential in art, see Michael Cole, Cellini and the Principles of Sculpture (New York: Cambridge University Press, 2002); idem, Ambitious Form: Giambologna, Ammanati, and Danti in Florence (Princeton: Princeton University Press, 2011); Bissera Pentcheva, "The Performative Icon," Art Bulletin 88, no. 4 (2006): 631-655; Georges Didi-Huberman, Ex-voto: image, organe, temps, (Paris: Bayal, 2006); Katie Lloyd Thomas, ed., Material matters: architecture and material practice, (London: Routledge, 2007). For an inspirational approach to materiality of music, see Richard Wistreich, "Introduction. Musical material and cultural space," Renaissance Studies 26, no. 1 (2012): 1-12.

7 That resistance most often assumes the form of an expectation of art's conformity to political or social cultural history that is conceived as necessarily incorporating it. Thus it is a political position of historicism to assume and insist on a coherence between one form of history and another (in particular, political or social history and art history).

8 Georges Didi-Huberman, Images in Spite of All: Four Photographs from Auschwitz (Chicago and London: University of Chicago Press, 2008), 47. 
affective. ${ }^{9}$ An uneasiness with a purely historicist reading of the architecture and form of the Treasury Chapel in Naples prompts instead a consideration of the question of the matter of holiness, that is how we might consider its materiality as part of the production of holiness, and as more than brute matter or question of technique. The aim here is to draw into relation material and spiritual approaches that have too often excluded each other. This is to treat materials not simply as marker and limit of what they permit (whether technically or as brute matter), but as both sites of potentiality and part of the very process of exploration that constitutes material spirituality. The Treasury Chapel is a usefully refractive prism through which to do this, as its very material insistence has tended to defeat analysis. Thus this essay offers an excursion into two inter-related problems: the problem of materiality in relation to holiness and the problem of the baroque.

First, materiality. The humanities seem full to bursting these days with people examining something referred to (it seems to me very unhelpfully) as "material culture," spurred on by Bruno Latour. ${ }^{10}$ Yet, too often these discussions dissipate "materiality" either into a simple list of objects, in a curious obdurate residue outside analysis, or the material is immaterialized and treated as mere instantiation of idea. In almost all cases, the entirely arbitrary exclusion of "art" from "material culture" in these discussions is profoundly limiting. ${ }^{11}$ In fact, an important distinction can be drawn between, on one hand, understanding materials as sites of potentiality and, on the other, the reduction of architecture to material presence, to the strictly empirical, and to brute matter. There remains the possibility of linking materiality to the conceptual and ideational through the way in which matter works. ${ }^{12}$

Second, the baroque: that thorn in the flesh or sand in the oyster of academic art history, because without contemporaneous articulation. ${ }^{13}$ The Treasury Chapel of San Gennaro is in many ways characteristic of the sort of baroque architecture that is still too readily marginalized within art history as "excessive" or "over the top." The sociology of art neglects the technical processes and precise forms of works of art; while phenomenologies of perception slight the historical religious and cultural aspects of looking practices. Meanwhile historical approaches to the economy of redemption tend either to ignore materiality, reducing spirituality to liturgy or to conciliar determinations or to "practice" or "ritual," conceived as effected somewhere somehow either outside of or innocently (autonomously) alongside the material; or they reduce both holiness and the material to political and social concerns. I fully acknowledge that the socio-political is deeply significant in the formation of visual culture, but I seek here to locate a more precise interconnection between the material and the spiritual economies. Although my case study is the Treasury Chapel of San Gennaro, much of what I say extends beyond that particular instance.

Let us take two examples to explore these issues. First the celebrated vast bronze entrance gate by Cosimo Fanzago and second the silver reliquaries that occupy the chapel like guerillas. I treat the bronze of the chapel gate and the silver of the reliquaries-like San Gennaro's blood itself - not as essences to be excavated, but as qualities to be discovered or invented. How did San Gennaro's miracle work to produce the chapel in this regard?

9 The affective is not irrationalist. My principal case study here derives from my current book project (The Matter of Miracles, Manchester University Press, forthcoming) which explores forms of holiness in baroque Naples, encompassing architecture, frontispieces, depictions of saints, and reliquaries.

10 Bruno Latour, Reassembling the Social. An introduction to actor-network-theory (Oxford: Clarendon 2005); Henry Glassie, Material Culture (Bloomington: Indiana University Press, 1999); Carl Knappett, Thinking through Material Culture: an interdisciplinary perspective (Philadelphia: University of Pennsylvania Press, 2005); Daniel Miller, Anthropology and the Individual: A Material culture perspective (New York: Berg, 2009); Ian Woodward, Understanding Material Culture (Los Angeles \& London: Sage, 2007).

11 Indeed, art has the greatest potential to explore the questions that materiality poses. See footnote 5 above.

12 See Andrew Benjamin, "Plans to Matter: Towards a History of Material Possibility," in Material matters: architecture and material practice, ed. Katie Lloyd Thomas (London: Routledge, 2007).

13 For a summary of the issues, see Helen Hills, ed., Rethinking the Baroque, (Farnham: Ashgate, 2011). 


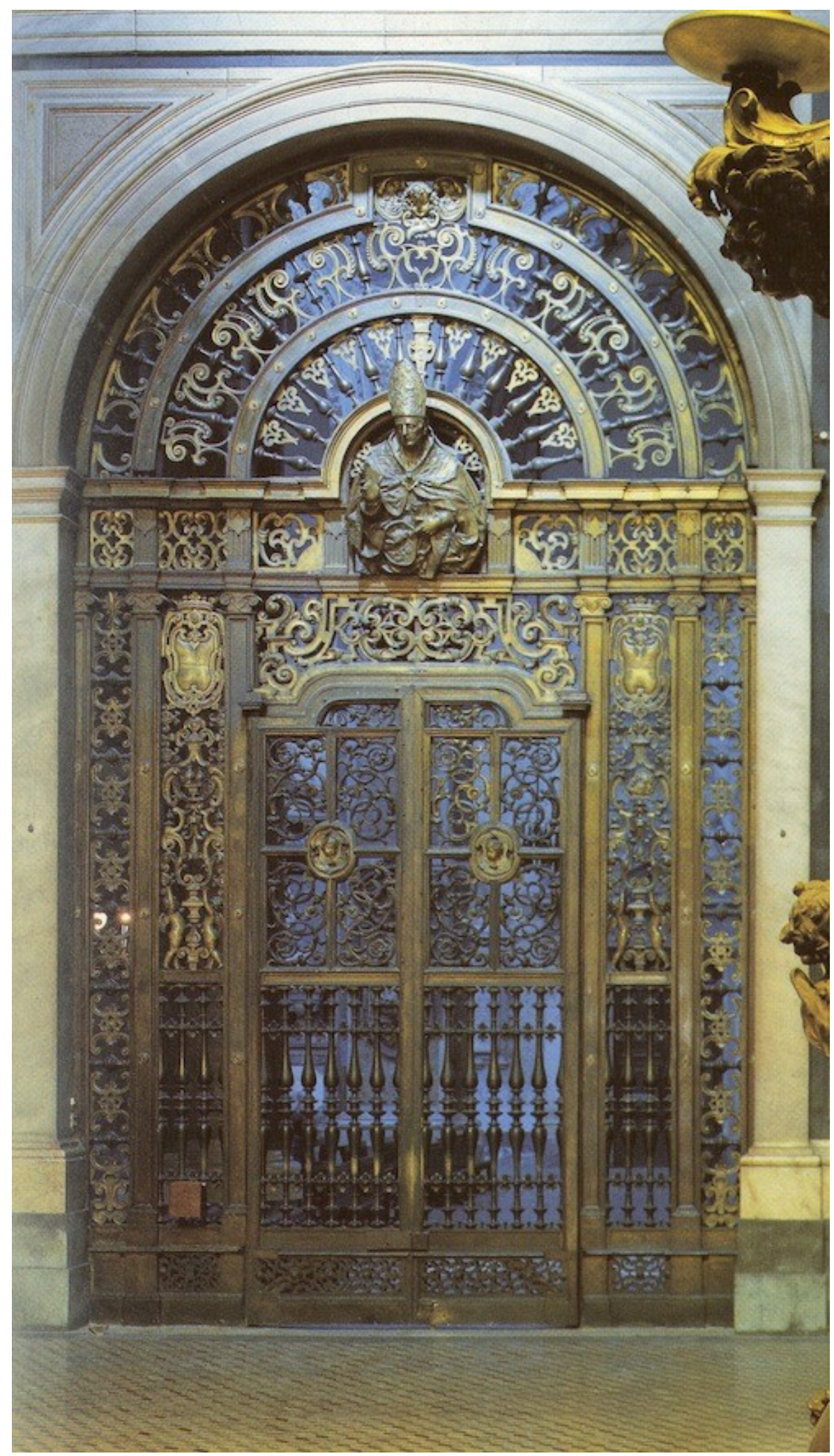

Fig 5 Cosimo Fanzago, Entrance gate to the Treasury Chapel of San Gennaro (1628-1669). Bronze and gilt bronze. Photo (C) Massimo Velo. By kind permission of the Eccellentissima Deputazione della Reale Cappella del Tesoro di San Gennaro. 
Cosimo Fanzago's formidable bronze gateway to the chapel (Figs. 2 \& 5) has to date been studied principally either in relation to its fraught patronage history between 1628 and 1669 or as a prodigal technical achievement in sculpture and bronze casting. ${ }^{14}$ Instead here I want to consider the gate in its work of staging the miracle of the liquefaction of San Gennaro's blood. The bronze of the gate is analogous to the blood of the miracle. Shapeshifting bronze is a good analogical material for the blood of San Gennaro: from something solid to something liquid and back again. If we consider it as an opening and barrier to the chapel, we see immediately that, far more than a mere screen between one space and another, the gate extends the division itself and works to stage the chapel as a chamber of transformation.

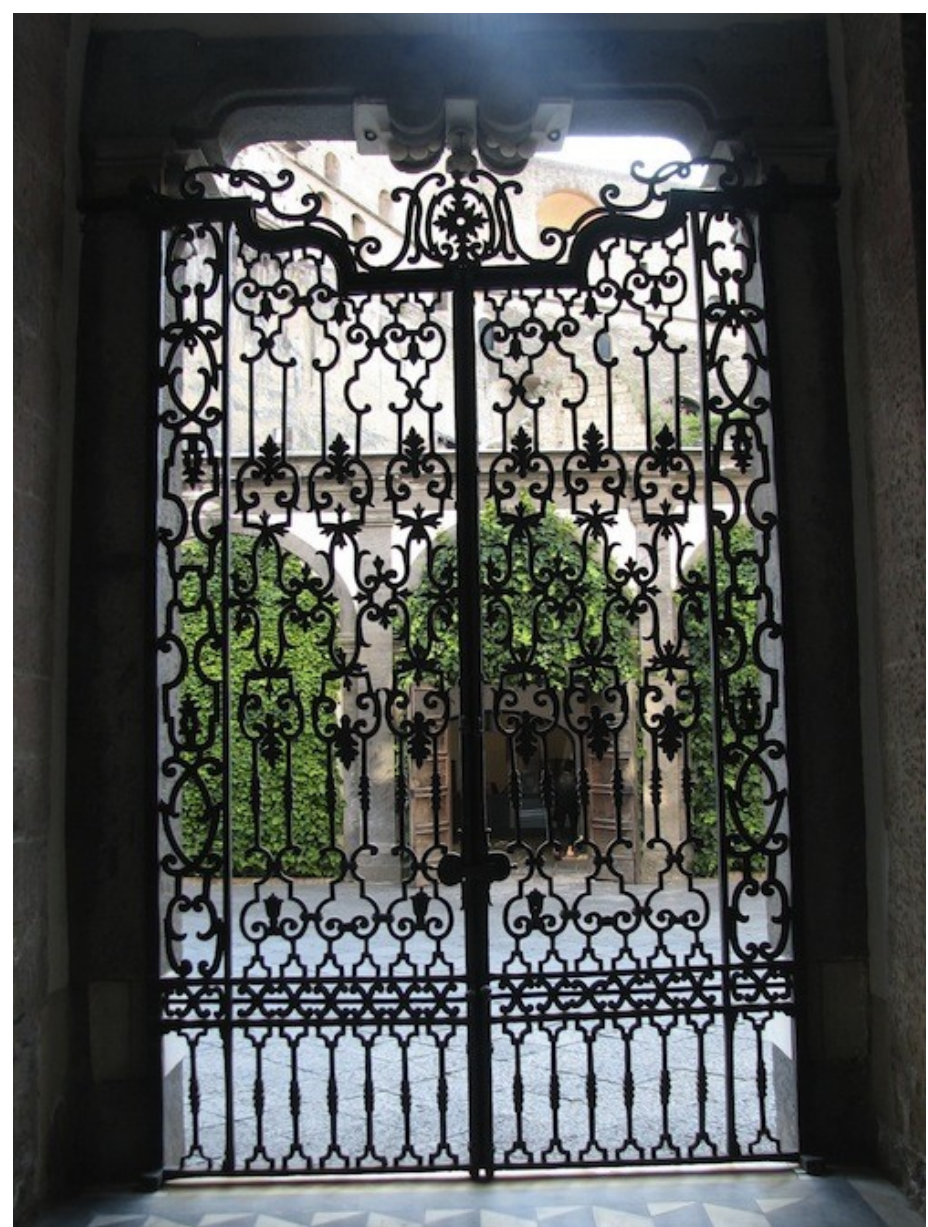

Fig 6 Naples, S. Martino. Entrance gate; probably of the late seventeenth century by Bartolomeo Antonio Picchiati or Luise Nauclerio. Photo $\subset$ Helen Hills

14 In 1623, Giovan Giacomo di Conforto was commissioned to design a great bronze gate for the chapel, a design accepted with some modifications in that same year. The Deputation ordered a model of wood to Conforto's design. A design by Cosimo Fanzago, under consideration in 1629 and apparently developed during 1630, appears to have been set apart, until June 1630 when di Conforto died, and the Deputation adopted Fanzago's design. Fanzago was assisted in the work of casting the bronze by Orazio Scoppa, Biase Monte, and Onofrio d'Alessio. On the gate, see E \& C Catello, La Cappella del Tesoro di San Gennaro (Naples, 1977), 72; Franco Strazzullo, La Cappella di San Gennaro (Naples, 1994), 15-16. For Giovan Giacomo di Conforto, see Franco Strazzullo, "La Corporazione napoletana dei fabbricatori, pipernieri e tagliamonti," Palladio 14, 1964; Idem, La Real Cappella, 1978, 17-19; P. Pietrini, L'opera di Giovan Giacomo Conforto, architetto napoletano del '600: Appunti per una ricerca (Naples: M. D'Alessandro, 1972). See most recently Paola d'Agostino, Cosimo Fanzago Scultore (Naples: Paparo Edizioni, 2011), 288-289. 
In differentiation from a gate like that of the church of the Certosa di San Martino, Naples, (Fig. 6) which is conceived in two dimensions, a pattern stretched across an opening, like a perforated skin over a drum, the Treasury gateway (Fig. 5) has a thickness to it that produces sculptural elements within its depth. When the gate is closed, from close to, face against metal, one can peer through its involutions into the chapel, but from further away the backlighting serves to produce a splintered silhouette that is a form of fractured closure, an unassailable barrier. When open, the gate is not just the place to change your pace, but itself an elongation, to catch your breath, your spiritus, as you enter the compression chamber. The gate, in its massy solidity and thickness, acts like a brake, slowing the transition, emphasizing the materiality of boundary, producing itself not as a division but as a connection, allowing the figure of San Gennaro to mark the edge and relation between cathedral and chapel, between that which is kept out and that which is let in. ${ }^{15}$

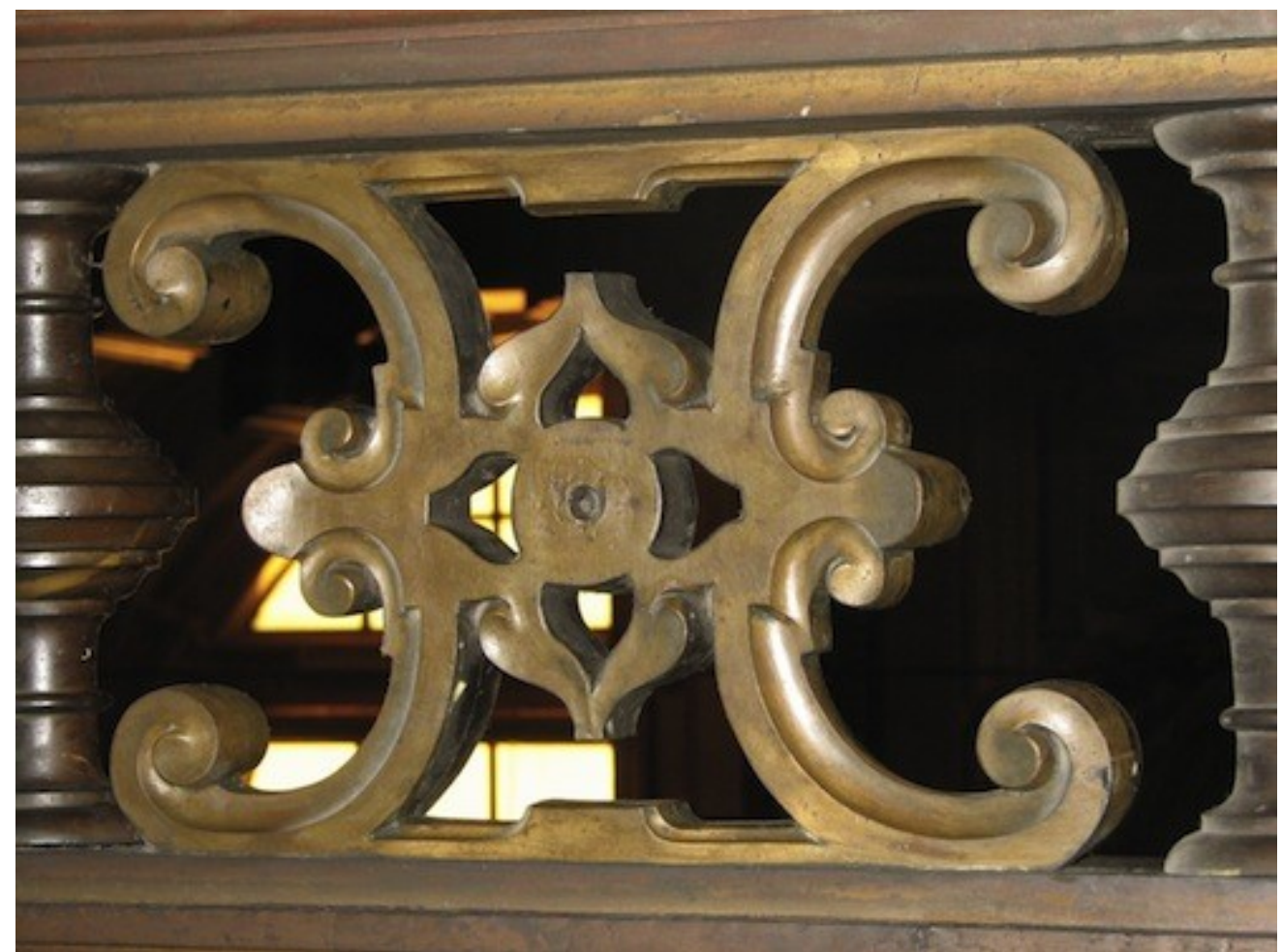

Fig 7 Treasury Chapel of San Gennaro. Detail of entrance gate. Photo C Helen Hills. By kind permission of the Eccellentissima Deputazione della Reale Cappella del Tesoro di San Gennaro.

The fascination of the mysterious alphabet wrought in bronze (Fig. 7) is a fascination for feeling anew, for the pause before entering, not to create a liminal space of ambiguity on the threshold, but the change of pace, the slowing of step, and quickening of heartbeat as you enter the darkened chapel, aglimmer with saints' reliquary busts. This chamber (Fig. 3) is a place where things become something else, and in entering which you too are changed. The Ionic order of the entrance gate is at once extraordinarily elongated and extremely narrow, as if it has been stretched in its liquid state (Figs. 2 \& 5).

Staunch bronze triglyphs stamp their way across the opening of the pierced frieze (Fig.5). They support skeletal segmental "pediments," or their rib-like carcasses. Thus a decorative element, the triglyph, assumes a quasi-structural role, as support for the pseudopediment, which is itself reduced to a decorative band, in a crossing between architecture and

15 The jurisdiction of the Deputation of San Gennaro extended beyond the door into the right nave as indicated by three inscriptions on the floor, but the gate is the architectural marker of greatest formal significance. 
decoration that interrogates, excavates, and hollows out the role of classicism, an effect heightened by the contrasts between the shiny gold bronze of the rib and the dark oily green of the bust. As the architectural orders are elongated, stretched to schematic marks of scansion between iconographical symbols and virtuoso technical mastery of bronze metal, the space within the gate itself is opened up in depth. The architectural order stretches the grille vertically as if towards heaven, as if freed from the restraints of gravity and with it of the classical idiom itself.

"He died, beheaded, that he could come to the head of his victories," writes the Jesuit Giacomo Lubrani in his 1695 panegyric of San Gennaro. ${ }^{16}$ On both sides of the gate San Gennaro leans outwards and downwards (an invention by Fanzago). That straining against and being uncontainable within the frame is a not uncommon feature of baroque marble sculpture, such as Gian Lorenzo Bernini's marvellous busts of Monsignor Pedro de Foix Montoja (d.1630) in Santa Maria in Monserrato, Rome and Gabriele Fonseca of c.1668 in S. Lorenzo in Lucina in Rome (Fig. 8). ${ }^{17}$

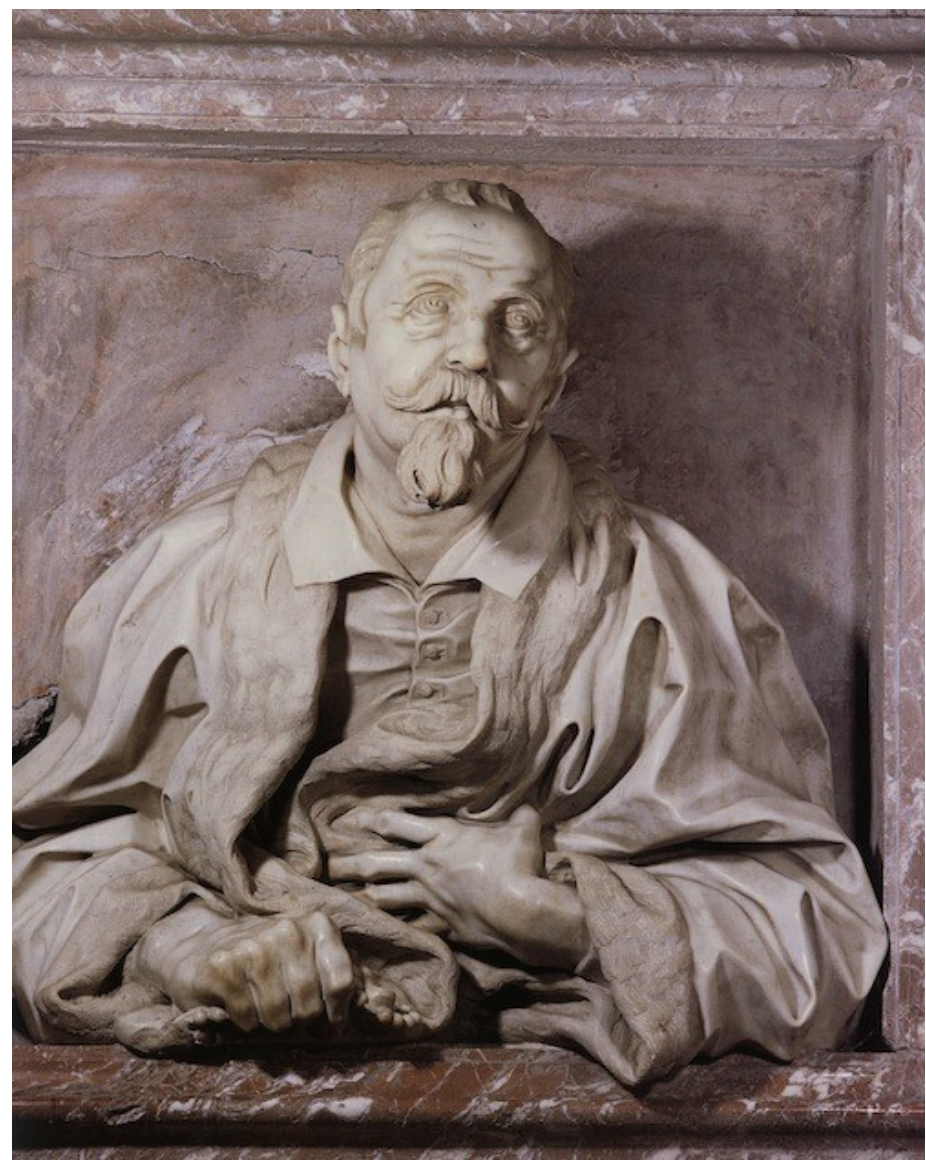

Fig 8 Gian Lorenzo Bernini, Gabriele Fonseca (d.1668), c.1668, San Lorenzo in Lucina in Rome.

16 Giacomo Lubrani, Il Fuoco Sacro della Divinità Racceso negl'Altari del Clero Mitrato e Religioso (Naples: Domenico Antonio Parrino \& Michele Luigi Muzio, 1694).

17 Bernini's bust of Monsignor Pedro de Foix Montoya, who dies in 1630, was executed towards the end of 1622. The design for the rest of the memorial was made by Orazio Torriani for which a contract with Santi Ghetti was made with Montoya in March 1623. The monument was not completed until 1632. See Oreste Ferrari and Serenita Papaldo, Le sculture del Seicento a Roma (Rome: Ugo Bozzi, 1999), 283. The Fonseca Chapel commissioned from Gianlorenzo Bernini by Gabriele Fonseca, a Portuguese doctor, was in an advanced state in 1663 and was completed by 1664. Despite Rudolf Wittkower's dating of the bust to c.1668-75, it is likely that it was executed before Fonseca's death in 1668. Ferrari and Papaldo, Le sculture del Seicento, 186-7. 
San Gennaro, however, is wrought in bronze, in an openwork gate, and operates in two opposing directions simultaneously, forward and backward. Such an extroverted figure is most remarkable. Not simply virtuosic, it animates the gateway itself, and produces the sense of an all-encompassing tutelary figure. At once intimidating and imploring, St Januarius, like Januas, looks in two opposing directions. He leans out, away from the grille, in an imprecatory gesture, out to the cathedral, the city and beyond, to the world of Vesuvius, plague, and earthquakes, while his alter ego looks inwards towards the chapel's altar and the relics, to miraculous glimpses of heaven. Thus, the figures of the saint in the door, like the relics themselves, like Januas at the beginning and end of the year, mediates between threat and place, earth and heaven, can look forwards and backwards simultaneously, be here and also there. Most gateways simply enclose or cut off. This gateway separates but draws together; divides but scans.

Janus, the ancient god of doors, from city gates to humble residences, in Ovid's Fasti presides over the gates of heaven, here Gennaro, is janitor to heaven, and the gate effectively represents the gateway to heaven, via San Gennaro. ${ }^{18}$ Thus, the Ianua Coeli, the 'door' to heaven, produces Ianuarius as gateway to heaven. And the conceit is thrown wide to all who enter there.

Crucially, the gate embodies the relationship between Gennaro and Vesuvius, of which relationship the miraculous liquefying blood was also part embodiment. ${ }^{19}$ The saint looks out

18 Referring to Oliviero Carafa's use of the Janus weight emblem on his Succorpo door, Norman observes that in his commentary on the opening passage of Ovid's Fasti, where Janus presides over the gates of Heaven, Giovanni Pico della Mirandola reserves the symbol of Janus for "celestial souls," a text that Carafa could have known. Diana Norman, "The Succorpo in the Cathedral of Naples: 'Empress of all Chapels", Zeitschrift für Kunstgeschichte 49, no. 3 f.n. 68 (1986):, 49.3, f.n. 68, 351-23-51.

19 This is a complex relationship which I seek to develop in my forthcoming book. For San Gennaro, see Paolo Regio, Vite dei sette santi protettori di Napoli (Naples: Giuseppe Cacchii, 1573; 1579); Loise Ioele, Rapresentatione, della vita del glorioso S. Gennaro vescouo di Beneuento, patritio, et protettore di Napoli. Del dottore Loise Ioele Napoletano (Naples: per Camillo Cauallo, 1645); Camillo Tutini, Memorie della Vita Miracoli, e culto di San Gianuario martire Vescovo di Benevento, e principal protettore della Città di Napoli (Naples: Ottavio Beltrano, 1633); Girolamo di Maria di Sant'Anna, Istoria della vita, virtù, e miracoli di S. Gennaro Vescovo e martire (Naples: Felice Mosca, 1707, 1733); idem, Aggiunte all'Istoria della Vita di S Gennaro Vescovo e martire (Naples: Felice Mosca, 1710). The miraculous blood is kept in two glass ampoules, enclosed in a reliquary or teca which is circular and circa $12 \mathrm{~cm}$ in diameter. The ampoules are unequal in size: one is large, elliptical in section, with capacity of about $60 \mathrm{cc}$; the other is smaller cylindrical in shape capacity of about $25 \mathrm{cc}$. See Giovanni Battista Alfano and Antonio Amitrano, Il Miracolo di S Gennaro: Documentazione Storica e Scientifica, $2^{\text {nd }}$ edition (Naples: Vincenzo Scarpati, 1950), 59. Tutini states that the first liquefaction occurred in 381 when San Gennaro's head and blood were reunited in Naples, but that the first time that it was displayed to the people is not recorded; for him this confirms its antiquity: "when an ecclesiastical rite recognized by all is of unknown origin, it is clear that it is extremely old and is a tradition of the ancient Christians". Tutini, 1710, 104; The event of 1389 is recorded in the Cronicon Siculum incerti authoris ab anno 340 ad annum 1396 in forma diary [sic] ex inedito Codice ottoboniano Vaticano, cura et studio Josephi de Blasiis, in Società Napoletana di storia patria. Monumenta storici, serie 1, Cronache, Naples, 1887. One of the best-known early sources is a poem of two hundred octaves, written mainly in Italian, by the Sicilian Fra Bernardino, a member of the Franciscan community in Naples and a doctor in canon law, which celebrates the life, martyrdom and miracles of San Gennaro, probably written over a period of time between 1503 and 1505. It records that when two phials containing the saint's dried blood were placed next to the reliquary containing the skull, the blood was liable to liquefy. Fra Bernardino's reference to the miracle occurring on a May feast day appears to be the earliest documentary reference to this liturgical event. The 1337 ritual of Archbishop Giovanni Orsini required that the passio of San Gennaro be commemorated on September 19th, and that on the first Saturday in May his translation be re-enacted. On that day, the head of the saint was carried from the cathedral to a church in the city and then returned to the cathedral in the afternoon, attended by the archbishop and clergy. The blood is recorded in the archiepiscopal records as accompanying the head to perform the miracle only after 1525 (Tutini, 1633, 98), although earlier records of the miracle antedating the sixteenth century exist, including 6 October 1496 (Giuliano Passero, Giornali, ed. V.M. Altobelli, [Naples, 1785], 108). See Diana Norman, "The Succorpo in the Cathedral of Naples: 'empress of all chapels,"” Zeitschrift für Kunstgeschichte 49, no. 3 (1986): 
towards the volcano and inwards towards his own blood; and he holds them apart in apotropaic relation..$^{20}$ The reforging of the relationship between Gennaro and Vesuvius occurred in 1631 when he dramatically intervened to prevent Naples' extinction. The sacred relics of San Gennaro processed to the outer reaches of the city and raised up towards the spitting mountain alone calmed the volcano and quenched the threat to Naples. At the same moment, the figure of San Gennaro blessing the people, appeared above the entrance of Naples Cathedral itself. In the Treasury Chapel gate the blessing saint refers to that momentous portent, affirming the connection and the promise. Thus in the gate Fanzago marries the blessing saint directly to the chapel and the blood.

Gennaro's ritual gesture of hand and fingers denotes the episcopal sign of the cross, with which as bishop he healed, prevented, and protected. The gesture is thaumaturgical, but it is also distinctively liturgical and an important source of the bishop's power. ${ }^{21}$ It denotes the bishop-protector saint Gennaro; and it indicates starkly that the Treasury Chapel is not part of the Cathedral's jurisdiction. It separates, even as it connects. But Fanzago's gates do more than mark a distinction between the provinces of the cathedral space and of the Chapel's lay Deputation..$^{22}$ The half-length figure and the ampoules of blood evoke Gennaro's martyrdom, the repeated miracles, and the presence of the saint (Figs. $5 \&$ 9).

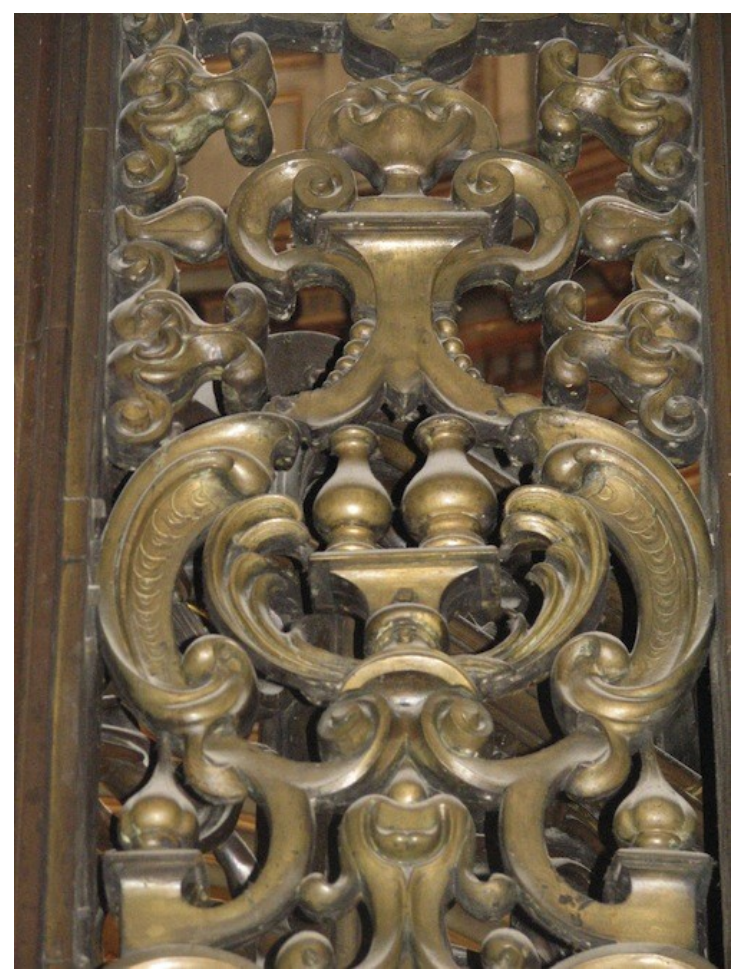

Fig. 9 Treasury Chapel gateway. Ampoules of blood. Photo (C) Helen Hills. By kind permission of the Eccellentissima Deputazione della Reale Cappella del Tesoro di San Gennaro.

\section{$331-2$.}

20 I do not, of course, mean (as one reader assumed) that the saint literally "looks out." The fact that the busts face in opposing directions indicates an emphatic engagement with both the chapel and the outside world beyond it.

21 Cynthia Hahn, Portrayed on the Heart. Narrative Effect in Pictorial Lives of Saints from the Tenth through the Thirteenth Century (Berkeley and London: University of California Press, 2001), 159.

22 For the patronage of the chapel by the Deputazione del Tesoro di San Gennaro, see Helen Hills, "The Neapolitan Seggi as Patrons of Religious Architecture: The Treasury Chapel of San Gennaro and Urban Holiness," in Ordnungen des Sozialen Raumes. Die Quartieri, Sestieri und Seggi in den frühneuzeitlichen Städten Italiens, ed. Grit Heidemann and Tanja Michalsky (Reimer: Berlin, 2012), 159-88. 
Since Antiquity, bronze was regarded as apotropaic, an effective means of warding off evil influence. ${ }^{23}$ Blood and bronze can be thought of as analogous, if we think of the miracle in terms of the desires it generates in relation to its solid and fluid states. In the gate, the ampoules containing and restraining the blood are counterpoint to the flow of bronze. The doors bind blood and bronze and prophylactic miracle together. Just as in the miracle the blood heated up and boiled, just as the volcano transformed rock to liquid, so the bronze of the gate was transformed through heat. Here heat is the implied metaphor for the transformation of both the bronze and the blood, and for the fires of Vesuvius which the chapel, the gate, and the blood were to hold at bay.

It is heat that sets things in motion. The blood boiled; and the bronze was cast through heat to proclaim the triumph of Januarius, to keep at bay the molten lava of Vesuvius' spew. Bronze and blood contained the cosmic elements of earth, water, air and fire. Fire burned through the chapel's blood. The blood liquefied by divine heat and transformed from solid to liquid, just as Vesuvius transformed solid rock to molten lava. Fire forged urban devotion and bronze metal into protective celebratory form.

I turn now to my second example of the silver reliquaries. The Treasury Chapel was above all a reliquary chapel for Naples' protector saints. Relics were not simply moved from one point to another (translation); in that movement they transformed and became (variation). And, on assuming residence in the chapel, each new reliquary statue altered it, acquiring a power superior to human nature. Thus in contrast to the earlier Renaissance Succorpo chapel, which foregrounded the body of Cardinal Carafa as patron and worshipper and presented San Gennaro largely in terms of his bones, the Treasury Chapel foregrounds the bodies of the saints. ${ }^{24}$

Christian sanctity can be described as a journey inscribed on the body and this was emphatically registered in the Chapel. ${ }^{25}$ The capacity to dominate one's body, to live beyond the limits of human nature was not only fundamental to the social recognition of supernatural exceptionality but was here brought to the fore. The saint who had vanquished nature in his

23 For pertinent accounts of bronze, see Jennifer Montagu, Gold, Silver and Bronze: Metal Sculpture of the Roman Baroque (Princeton: Princeton University Press, 1996); Antonio Iacobini, "Le porte di bronzo dall'antichità a secolo XIII," Arte medievale 2, no. 2 (1988): 287-97; L. Pozzi, Le porte artistiche di bronzo degli edifizii monumentali, religiosi, e curali d'Italia (Bergamo: Istituto italiano d'arti grafiche, 1903); Cole, Cellini; Francesca Bewer, “The 'De la pirotechnia' of Vannoccio Biringucci and bronze sculpture,” Unpublished M.Phil dissertation, Warburg Institute, London, 1995; A. Radcliffe and N. Penny, Art of the Renaissance Bronze, 15001650 (London: Philip Wilson, 2004); David Ekerdjian and Christopher Le Brun, Bronze, (London: Royal Academy of Arts, 2012).

24 For a discussion of the Treasury Chapel in relation to the Succorpo Chapel, see Hills, "The Neapolitan Seggi as Patrons of Religious Architecture," 166-74.

25 For a rich discussion of sanctity as a journey inscribed on the body, see Peter Brown, The Cult of the Saints: its Rise and Function in Latin Christianity (Chicago: Chicago University Press, 1981) and Caroline Walker Bynum, Holy Feast and Holy Fast (Berkeley: University of California Press, 1988). The richest discussion of Neapolitan sanctity remains Jean-Michel Sallmann, Naples et ses saints à l'âge baroque (1540-1750) (Presses Universitaires de France, 1994); Santi barocchi: Modelli di santità, pratiche devozionali e comportamenti religiosi nel regno di Napoli dal 1540 al 1750, trans. Carla Rabuffetti (Lecce: Argo, 1996). See also Giuseppe Galasso, Napoli capitale: identità politica e identità cittadina. Studi e ricerche 1266-1860 (Naples: Electa, 1998); idem, "Ideologia e sociologia del patronato di San Tommaso d'Aquino su Napoli (1605)," in Per la storia sociale e religiosa del Mezzogiorno d'Italia, eds. G Galasso and C. Russo, vol. 2, (Naples: Guida, 1982); Maria Antonietta Visceglia, Identità sociale. La nobiltà napoletana nella prima età moderna (Milan: Edizioni Unicopli, 1998); Giovanni Muto, "Sacred Places in Spanish Naples," in Frontiers of Faith, eds. Eszter Andor and István György Toth (Budapest: Central European University, 2001); Laura Barletta, Fra regola e licenza: chiesa e vita religiosa, feste e beneficenze a Napoli e in Campania (secoli XVIII-XX), (Naples: Edizioni Scientifiche Italiane, 2003); Vittoria Fiorella, Una santa della città: Suor Orsola Benincasa e la devozione napoletana tra Cinquecento e Seicento (Naples: Editoriale Scientfica, 2001). Most recently on San Gennaro, see San Gennaro nel XVII Centenario del martirio (305-2005), ed. Gennaro Luongo, 2 vols, (Naples: Campania Notizie Srl, 2007). 
spirit and body could dominate nature, could protect and heal and defeat death, including on behalf of others. The Treasury Chapel was superabundantly inhabited by relics and saints and, by extension, by external institutions which were invested in the chapel through their espoused saints. In short, the effect was not of simple population, but of over-population, a synthesis of heterogeneity, of saintly reproduction and overflow (Figs. $3 \&$ 4).

The relics themselves comprised a vast variety of bones: ranging from entire skulls to fragments of leg and arm bones. Of the relics only San Gennaro's was actually the head (Fig.10). Yet, all the saints were represented by silver reliquary busts or half-length figures (Fig.12), producing an effect of uniformity and coherence, of an army of saints subordinated to Gennaro, to the chapel, and to the city as a whole (Figs $3 \&$ 4).

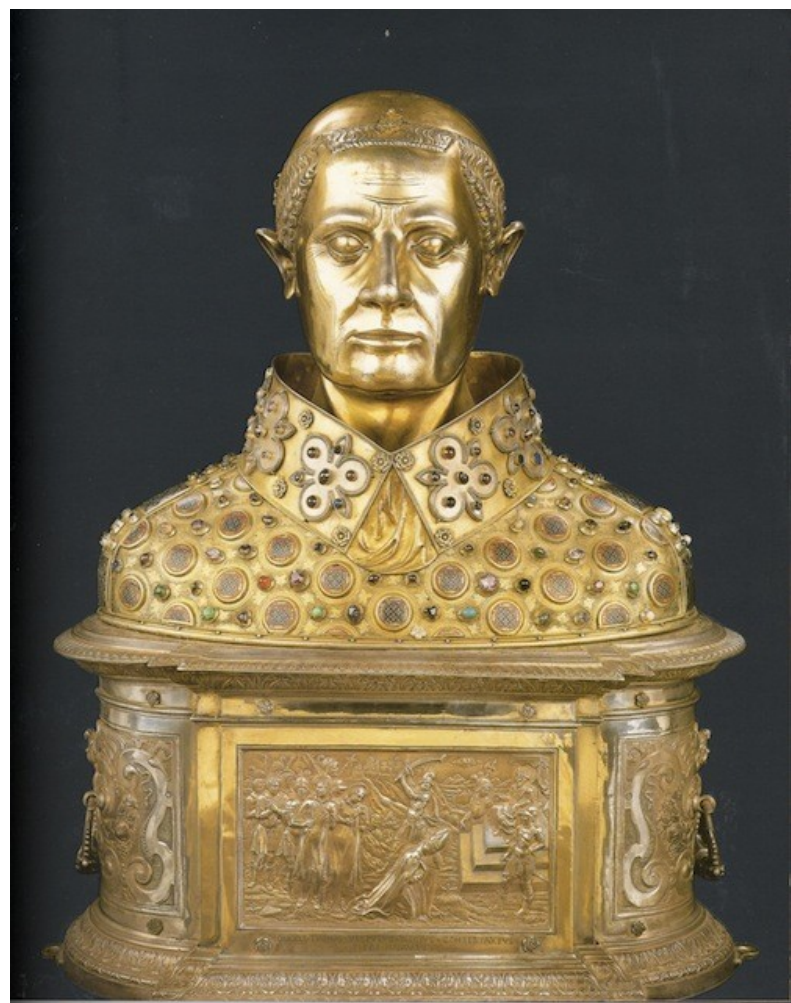

Fig 10 Mastro Étienne, Godefroy, Milet d'Auxerre, Guillaume de Verdelay and Milet d'Auxerre, Reliquary bust of San Gennaro (1305), Treasury Chapel of San Gennaro, Naples. By kind permission of the Eccellentissima Deputazione della Reale Cappella del Tesoro di San Gennaro.

The reliquaries made formal reference always primarily to the magnificent reliquary bust of 1305 of San Gennaro commissioned by King Charles II (Fig. 10). He set the gold standard. His was the first bust and remains the only one in the chapel made of gilt silver, splendid in its almost oily golden opulence, studded with precious stones. ${ }^{26}$ The bust form of the silver reliquaries therefore both indicated their dependence on San Gennaro and referred

26 Barbara Boehm suggests that at the end of the thirteenth century it mattered that the head reliquary of France's royal saint Louis resemble the head reliquary of Saint Denis in appearance and construction, since thus the visual metaphor served to link the saints. Barbara Drake Boehm, "Body-Part Reliquaries: The State of Research,"” Gesta 36, no. 1 (1997): 16. See also C. Enlart, "L'Emaillerie cloisonné à Paris sous Philippe le Bel," in Monuments et mémoires publiés par l'Académie des inscriptions et belles-lettres 29 (Fondation Eugene Piot), (1927-28): 36. 
synecdochally to the saint in Heaven, that is to each saint elsewhere, whole and complete, while what they contained was only part, truncated, martyred, of the earth. There remains something unnerving about the amassed gathered heads in the chapel. ${ }^{27}$ They upset any easy boundary between Heaven and earth, life and death, sculpture and cultic object, indeed, between subject and object. They do more than inhabit the chapel. Their slippery presence, which depends on their very absence, and implies always a presence elsewhere, can only discomfit the too stolidly embodied visitor.

The reliquary busts were a means of being passionately; they did not simply "represent" the saints. They extended the action of the chapel, the involvement of the worshipper, as a "mechanosphere," a shifting, changing network and assemblage which cut across institutions and categories, including the holy and the secular, the biological and the architectural, social, economic, ecclesiastical and lay, with the boundaries of practice and meaning constantly changing. Thus the saints produced a chapel with boundless geographical extent and spiritual reach. ${ }^{28}$ The chapel consisted of traces which spilled over its boundaries.

In representations, San Gennaro is insistently depicted as a bust or half-length figure. Thus in Domenico Gargiulo's magnificent Eruption of Vesuvius of 1631 (Capua private collection) the saint flies overhead - but in abbreviated bust-like form (Fig. 11). Such images indicate that it was his reliquary that was seen to encapsulate San Gennaro's miraculous powers; his bust a fabulous synecdoche. ${ }^{29}$

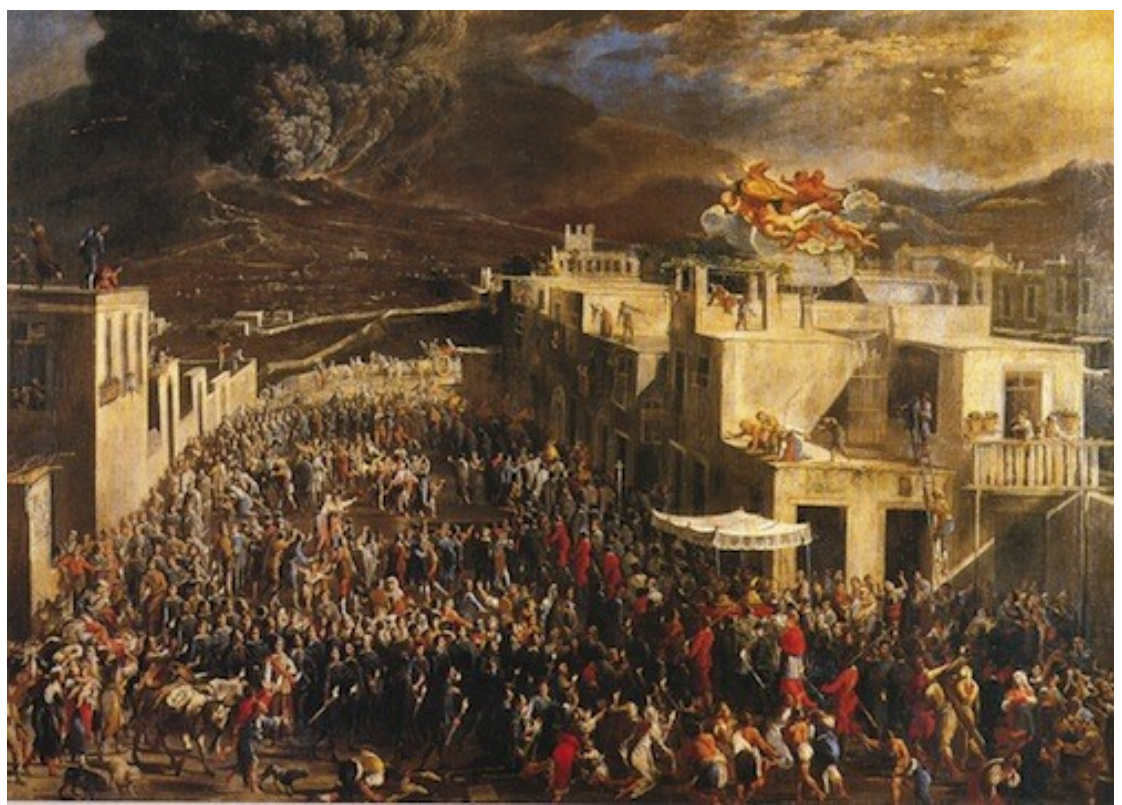

Fig 11 Domenico Gargiulo (Micco Spadaro), Eruption of Vesuvius of 1631 (Oil on canvas, Capua private coll.)

27 Linda Nochlin refers specifically to the gulf between medieval and late twentieth-century assumptions about body parts. See Linda Nochlin, The Body in Pieces: The Fragment as a Metaphor of Modernity (London: Walter Neurath Memorial Lecture 26, 1994). She suggests that depictions of fragments since the French Revolution have none of the medieval sense of pars pro toto. See Carolyn Walker Bynum and P. Gerson, "Body-Part Reliquaries and Body Parts in the Middle Ages," Gesta 36, no. 1 (1997): 3.

28 Henri Lefebvre pointed out that bounded spaces are spaces of transit, taking as his example the modern house whose boundaries are crossed by electrical wiring, water and gas pipes, sewage systems, radio waves, and the rest. See Henri Lefebvre, The Production of Space, trans. Donald Nicholson Smith (Oxford: Blackwell, 1991).

29 See Helen Hills, "The Face is a mirror of the soul: Frontispieces and the production of sanctity in postTridentine Naples," Art History 31, no. 4 (2008): 547-74; Idem, "How to Look like a Counter-Reformation Saint," in Exploring Cultural Histories: Essays in Honour of Peter Burke, eds. M. Calaresu, F. De Vivo and J.P. Rubies (Farnham: Ashgate, 2010), 207-30. 


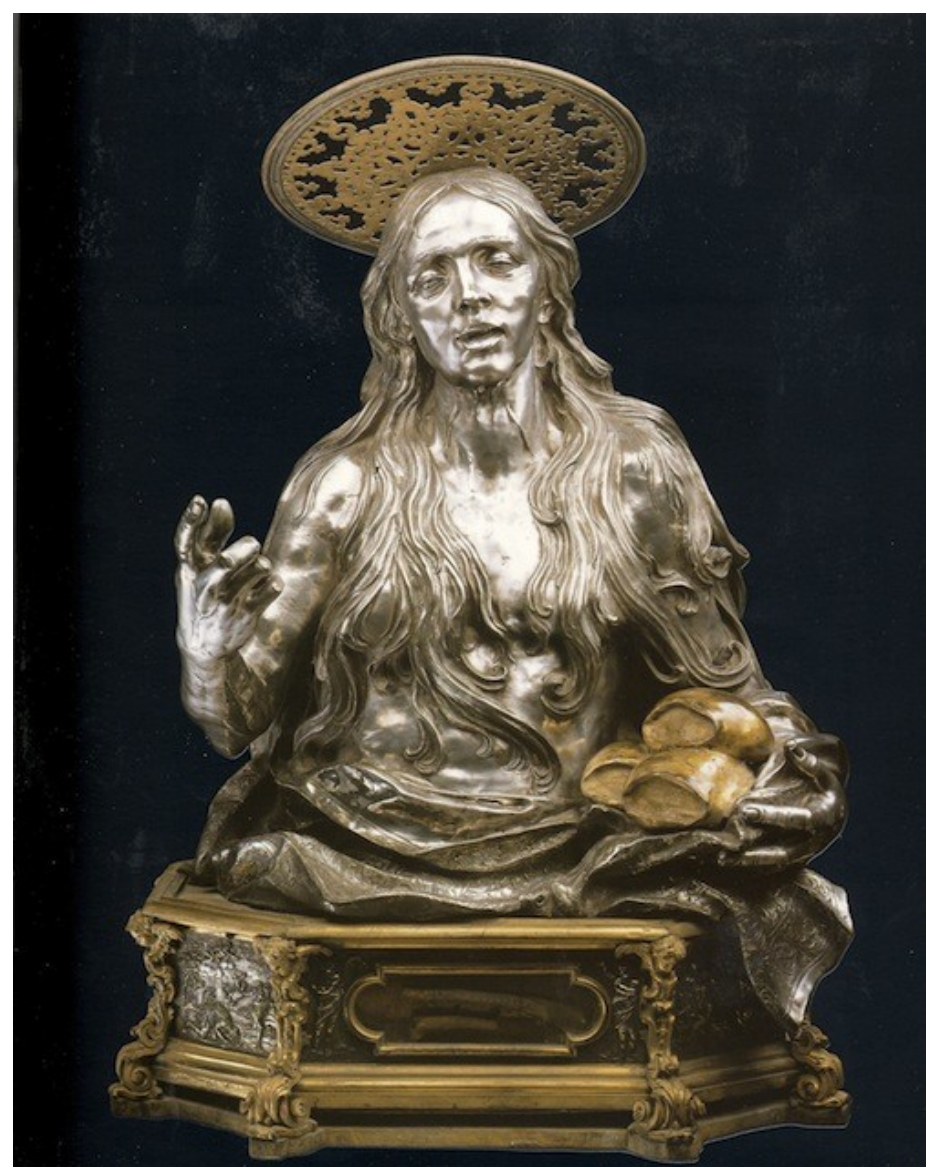

Fig 12 Lorenzo Vaccaro (attrib), St Mary of Egypt, 1691. Silver reliquary in the Treasury Chapel of San Gennaro. By kind permission of the Eccellentissima Deputazione della Reale Cappella del Tesoro di San Gennaro.

The bust reliquaries are liberated from the restriction of scale and distracting detail that the full-length human form brings with it (Fig. 12). The form links the relic directly to the human body, especially to the mind and soul; but simultaneously frees it from being bound to mere corporeal appearance, thereby increasing its auratic intensity. This auratic intensification is part of the process whereby it enters into cultural circulation, in some way acceding to the status of an object both substitutable and mobile. ${ }^{30}$ More than mere sculptural busts of saints, the reliquary busts are heavily contaminated by contact: contact with the relics they contain and, through them, with Heaven and divine will. The palpable and material are therefore also the spiritual and transcendent.

Silver is a slippery substance, both material and color, substance and surface. An internal quality of the element, silver is a secret but precise quality that directly links density to surface and that produces its sheen. Silver, attracting and reflecting light, its lustre fracturing the world around it, produces ripples of reflection across the Treasury Chapel on even the darkest days, constantly bringing it to life and setting the relics apart from the everyday world. Precious silver declared the preciousness of the relics inside. In early modern Europe, massive amounts of silver from the Andean mines traversed the Atlantic, and more than any other commodity formed a world trade system involving especially China. ${ }^{31}$

30 Referring to an ex voto, Didi Huberman writes, 'Il se civilise, en quelque sorte, il accède à un statut d'objet substituable et mobilier.' Georges Didi-Huberman, Ex-voto: image, organe, temps (Paris: Bayard, 2006), 84.

31 Silver was the key commodity distributed globally and it was exchanged for items, mainly silk and porcelain, but also gold from the Asian mainland. Europeans were intermediaries in the silver trade between the New World and China. See Dennis O. Flynn and Arturo Giráldez, "Born with a 'Silver Spoon': The Origin of World 
Prodigious profits from the globalized silver industry provided much needed income to helpfinance the sprawling Spanish empire and repay its Genoese bankers. ${ }^{32}$

As many as 350 workshops of silversmiths were concentrated in Naples..$^{33}$ Silver added lustre to aristocratic status, transformed wealth into cultural capital. Noble Neapolitans boasted lustrous silver collections: small silver sculptures, adorned desks and other furniture. ${ }^{34}$ Silver was profit and power for the Spanish; its working in Spanish-ruled Naples contributed to that nexus; economically, politically, and materially.

Silver is shiny, smooth, gorgeous, and valuable; but it was above all a material of and for re-use and retransformation. Silver was malleable, the substance from which other objects had already been made; already passed on, already used, refashioned, reformed, and melted into liquid. It was the preferred medium of valuation and exchange. While the value of coins lay in their metal, not in the mint, silver could be assayed for purity, while copper could not. Price was set in silver. ${ }^{35}$ Malleable, reproductive, metamorphic; it was profit, the gain of flesh through material and through the material that it imitates. Silver, more than gold, therefore, was equivalent to exchange, the most mobile of currencies, the most exchangeable, and best able to represent something that was not itself. It represented the ability to shift one material into another, to transform and to trade in transformation, to cross continents and traverse cultures, to slip from one form to another, to exchange earth for heaven, and back again.

Silver's particular capacity to be purified lent itself to the production of chalice, pyx, and plate. Imbricated with the spiritual and material transformations of transubstantiation in the Mass, silver sacramental vessels bore those miraculous particles between God and man, altar and priest, priest and communicant. In the sacrament silver bridged the gap between doctrine and desire, between sin and grace. In Christ's words: "This cup is that new Testament in my blood, which is shed for you" (Luke, 22). As the priest drinks the blood of Christ, it is silver that transfers God to man, that transfers His incorporation. It is silver that communicates between the holy and the material and that permits their exchange.

Silver is a good analogical material for the currency of relics: apparent guarantor of value located elsewhere, yet always available through exchange. Saints' relics embody the promise of God's power to remake the human body at the resurrection. Thus the relic represents the concept of a future integration of flesh and spirit. Silver, as smooth surface replacing skin and flesh, operates to convey this conjunction of material analogy. "Silver is the soul and the blood of mortals," claimed Agricola. ${ }^{36}$ In the Treasury Chapel's reliquaries silver assumes the place of flesh and skin, resplendent with the bones that it covers. Human beings, as flawed vessels, sinful and mortal, could reach immortality through the silver saints. The silver reliquary vessels, pure and refined as they are, may be seen as embodying the promise of future physical perfection as members of the body of Christ.

Thus the silver reliquary busts become anticipation incarnate, the glory of the saint's body transfigured for eternity, reunited with its happy soul, on earth and in heaven. They are machinic: not sealed organisms so much as cathects, transforming and transformative. The

Trade in 1571," Journal of World History 6, no. 2 (Fall 1995): 201-21.

32 The financial foundation of the Spanish empire was based on resources outside the Iberian peninsula. The Spanish crown received huge wealth from its control and taxation (direct and indirect) of low-cost New World mines, especially Potosí. See Flynn and Giráldez, "Born with a 'Silver Spoon," 200-211. According to Earl Hamilton, $27.5 \%$ of total registered precious metals entering Seville between 1566 and 1645 belonged to the crown of Castile. See Earl Hamilton, American Treasure and the Price Revolution in Spain, 1501-1650 (Cambridge, Massachusetts: CUP, 1934), 34.

33 Corrado Catello, “Argenti," in Civiltà del Seicento a Napoli [exhibition catalogue, Naples 1985] (Naples: Electa Napoli, 1998), 307.

34 Catello, "Argenti," 307.

35 Flynn and Giráldez, "Born with a 'Silver Spoon,"” 207-08.

36 Georgius Agricola, De la generatione de le cose, che sotto la terra sono, e de le cause de'loro effetti e nature (Venice: Michele Tramezzino, 1563), 6. 
reliquary busts are therefore more than simple representations of saints. There is a textural connivance between their silver material and flesh. They combine and refract nature, artifice, and the holy. Virtus, the attribute of relics, permeates the silver flesh of the reliquary. The relics dwelled in a 'little house' with a fenestella or glass window, which was opened up for the miracle, and allows a glimpse through immeasurable time and space to the relic, allows the witnessing of that place where past and future, flesh and spirit, are one.

\section{Beyond Containment}

Interiors within interiors within interiors fracture any simple interior / exterior opposition to instead frame and reframe in a relation in which the smaller object, the relic, the fragment of bone, elides, and encompasses its multiple containers. The body-reliquary-tabernacle-chapel relation produces bodies within and without bodies, in relations that not only hold and protect, hide and reveal, but displace one substance with another through virtus from within.

Although they occupy a house within a house, a container within a container, the relics are never housed and never contained; instead they are always excessive, overflowing, spilling out, beyond simple placement. Opening these doors one after the other allows the inclusion in each other of what is usually excluded. Yet, despite the opening of repeated gates, doors, and windows, of chapel, of reliquary, in spite of their display, the relics remain also resolutely inaccessible, ever more distant and elusive, even as they become ever closer and more present. While the emphasis on and elaboration of doors and openings in the chapel implies a straightforward hermeneutics of depth, the problematic presence in heaven and on earth of the saint through the relic disturbs such an interpretation. Instead, we see a fracturing of those hermeneutics and the production of heterogeneous spaces and presences, which are incommensurable, even apparently incompatible. Gates, doors, and windows served to keep apart, but their opening could draw together, produce an access, a closeness, even a union, that depended for its production on that very separation and on those barriers.

The Treasury Chapel requires a gaze that would not draw close only to discern and recognize, to name and to order, to chronologize and taxonomize, but which would first be grasped, before grasping, which would let oneself go, in "letting go of one's knowledge about it," labyrinths in which knowledge loses its way, in which the system becomes a great displacement, a great multiplication of forms, images and surfaces, in which we must first lose ourselves - but, of course, not simply lose ourselves - before anything can be found. Indeed, as Deleuze has argued, art would be nothing more than opinion if it did not allow an element of chaos to enter in that transforms and mobilizes thinking. ${ }^{37}$ That destruction of opinion is achieved by disrupting the supposed harmony or unity of experience. The Deputation and the people of Naples perhaps thought themselves able to control the chapel. But, to no small a degree it produced them as custodians and worshippers of certain visions and effects of spirituality, in other words, what might be termed a "material spiritual production." In such ways, perhaps, the history of art might turn the material turn.

37 Gilles Deleuze and Félix Guattari, A Thousand Plateaus. Capitalism and Schizophrenia, trans. B. Massumi, (Minneapolis: University of Minnesota Press, 1994), 204. 
Agricola, Georgius. De la generatione de le cose, che sotto la terra sono, e de le cause de' loro effetti e nature. Venice: Michele Tramezzino, 1563.

Alfano, Giovanni Battista, and Antonio Amitrano. Il Miracolo di $S$ Gennaro: Documentazione Storica e Scientifica. Naples: Vincenzo Scarpati, 1950.

Barletta, Laura. Fra regola e licenza: chiesa e vita religiosa, feste e beneficenze a Napoli e in Campania (secoli XVIII-XX). Naples: Edizioni Scientifiche Italiane, 2003.

Bellucci, Antonio. Memorie storiche ed artistiche del tesoro nella Cattedrale: dal secolo 16. al 18. desunte da soli documenti inediti; con prefazione di G. Taglialatela. Naples: Antonio Iacuelli, 1915.

Benjamin, Andrew. "Plans to Matter: Towards a History of Material Possibility." In Material Matters: Architecture and Material Practice, edited by Katie Lloyd Thomas. London: Routledge, 2007, 13-28.

Bewer, Francesca. "The 'De la pirotechnia' of Vannoccio Biringucci and Bronze Sculpture," Unpublished M.Phil dissertation. Warburg Institute, London, 1995.

Boehm, Barbara Drake. "Body-Part Reliquaries: The State of Research." Gesta, 36, no.1 (1997): 8-19.

Brown, Peter. The Cult of the Saints: its Rise and Function in Latin Christianity. Chicago: Chicago University Press, 1981.

Bynum, Carolyn Walker, and P. Gerson. "Body-Part Reliquaries and Body Parts in the Middle Ages," Gesta 36, no. 1 (1997): 1-7.

Catello, Corrado. "Argenti." In Civiltà del Seicento a Napoli [exhibition catalogue, Naples 1985], 307. Naples: Electa Napoli, 1998.

Catello, Elio. "Argenti Napoletani del Seicento: considerazioni su documenti inediti." In Ricerche sul '600 napoletano (1998): 7-15.

Catello, Elio, and Corrado Catello. La Cappella del Tesoro di San Gennaro. Naples: Edizione del Banco di Napoli, 1977.

Celano, Carlo. Notizie del Bello dell'Antico e del Curioso della Città di Napoli. Edited by Giovanni Battista Chiarini. Naples: Agostino di Pascale, 1858.

Cerino, Vincenzo. San Gennaro: un santo, un voto e una cappella. Naples: Rolando Editore, 2005.

Cole, Michael. Cellini and the Principles of Sculpture. New York: Cambridge University Press, 2002.

. Ambitious Form: Giambologna, Ammanati, and Danti in Florence. Princeton: Princeton University Press, 2011

Cronicon Siculum incerti authoris ab anno 340 ad annum 1396 in forma diary [sic] ex inedito Codice ottoboniano Vaticano, cura et studio Josephi de Blasiis. In Società Napoletana di storia patria. Monumenta storici, serie 1, Cronache, Naples, 1887.

D’Agostino, Paola. Cosimo Fanzago Scultore. Naples: Paparo Edizioni, 2011.

Deleuze, Gillles, and Félix Guattari. A Thousand Plateaus. Capitalism and Schizophrenia. Translated by B. Massumi. Minneapolis: University of Minnesota Press, 1994.

Didi-Huberman, Georges. Ex-voto: image, organe, temps. Paris: Bayal, 2006. . Images in Spite of All: Four Photographs from Auschwitz. Chicago and London: University of Chicago Press, 2008.

Ekerdjian, David and Christopher Le Brun. Bronze. London: Royal Academy of Arts, 2012.

Enlart, Camille. "L'Emaillerie cloisonné à Paris sous Philippe le Bel." Monuments et mémoires publiés par l'Académie des inscriptions et belles-lettres 29, (1927-28): 35- 
36.

Ferrari, Oreste, and Serenita Papaldo. Le sculture del Seicento a Roma, Rome: Ugo Bozzi, 1999.

Fiorella, Vittoria. Una santa della città: Suor Orsola Benincasa e la devozione napoletana tra Cinquecento e Seicento. Naples: Editoriale Scientfica, 2001.

Flynn, Dennis O., and Arturo Giráldez. "Born with a 'Silver Spoon': The Origin of World Trade in 1571." Journal of World History 6, no. 2 (1995): 201-21.

Glassie, Henry. Material Culture. Bloomington: Indiana University Press, 1999.

Galasso, Giuseppe. Napoli capitale: identità politica e identità cittadina. Studi e ricerche 1266-1860. Naples: Electa, 1998.

. "Ideologia e sociologia del patronato di San Tommaso d'Aquino su Napoli (1605)." In Per la storia sociale e religiosa del Mezzogiorno d'Italia, edited by Giuseppe Galasso and Carla Russo, vol. 2. Naples: Guida, 1982.

Hahn, Cynthia. Portrayed on the Heart. Narrative Effect in Pictorial Lives of Saints from the Tenth through the Thirteenth Century. Berkeley and London: University of California Press, 2001.

Hamilton, Earl. American Treasure and the Price Revolution in Spain, 1501-1650. Cambridge, Massachusetts: Cambridge University Press, 1934.

Hills, Helen. "The Face is a Mirror of the Soul: Frontispieces and the Production of Sanctity in Post-Tridentine Naples." Art History 31, no. 4 (2008): 547-74.

. "How to Look like a Counter-Reformation Saint." In Exploring Cultural Histories: Essays in Honour of Peter Burke, edited by M. Calaresu, F. De Vivo and J.P. Rubies, 207-30. Farnham: Ashgate, 2010. . ed., Rethinking the Baroque, Farnham: Ashgate, 2011.

. "The Neapolitan Seggi as Patrons of Religious Architecture: The Treasury Chapel of San Gennaro and Urban Holiness." In Ordnungen des Sozialen Raumes. Die Quartieri, Sestieri und Seggi in den frühneuzeitlichen Städten Italiens, edited by Grit Heidemann and Tanja Michalsky. Reimer: Berlin, 2012.

Iacobini, Antonio. "Le porte di bronzo dall'antichità a secolo XIII.," Arte medievale 2, no. 2 (1988): 287-97.

Ioele, Loise. Rappresentazione della vita del glorioso S. Gennaro, vescouo di Beneuento, patritio et protettore di Napoli. Naples: Camillo Cavallo, 1645.

Knappett, Carl. Thinking through Material Culture: an Interdisciplinary Perspective. Philadelphia: University of Pennsylvania Press, 2005.

Latour, Bruno. Reassembling the Social. An introduction to Actor-Network-Theory. Oxford: Clarendon, 2005.

Lefebvre, Henri. The Production of Space. Translated by Donald Nicholson Smith. Oxford: Blackwell, 1991.

Lloyd Thomas, Katie. ed., Material Matters: Architecture and Material Practice. London: Routledge, 2007.

Lubrani, Giacomo. Il Fuoco Sacro della Divinità Racceso negl'Altari del Clero Mitrato, e Religioso. Naples: Domenico Antonio Parrino \& Michele Luigi Muzio, 1694.

Luongo, Gennaro, ed., San Gennaro nel XVII Centenario del martirio (305-2005), 2 vols. Naples: Campania Notizie Srl, 2007.

Maria di Sant'Anna, Girolamo. Istoria della vita, virtù, e miracoli di S. Gennaro Vescovo e martire. Naples: Felice Mosca, 1707.

Istoria della vita, virtù, e miracoli di S. Gennaro Vescovo e martire. Naples: Felice Mosca, 1733.

Aggiunte all'Istoria della Vita di S Gennaro Vescovo e martire. Naples: Felice Mosca, 1710. 
Miller, Daniel. Anthropology and the Individual: A Material Culture Perspective. New York: Berg, 2009.

Montagu, Jennifer. Gold, Silver and Bronze: Metal Sculpture of the Roman Baroque. Princeton: Princeton University Press, 1996.

Muto, Giovanni. "Sacred Places in Spanish Naples." In Frontiers of Faith, edited by Eszter Andor and István György Toth. Budapest: Central European University, 2001.

Nochlin, Linda. The Body in Pieces: The Fragment as a Metaphor of Modernity, No. 26 Walter Neurath Memorial Lecture. London: Thames and Hudson, 1994.

Norman, Diana. "The Succorpo in the Cathedral of Naples: "Empress of all chapels." Zeitschrift für Kunstgeschichte 49, no. 3 (1986): 68, 323-51.

Passero, Giuliano. Giornali, ed. V.M. Altobelli. Naples, 1785.

Pentcheva, Bissera. "The Performative Icon.” Art Bulletin 88, no. 4 (2006): 631-55.

Pietrini, Paolo. L'opera di Giovan Giacomo di Conforto, architetto napoletano del '600 appunti per una ricerca. Naples: M. D'Alessandro, 1972.

Pozzi, L. Le porte artistiche di bronzo degli edifizii monumentali, religiosi, e curali d'Italia. Bergamo: Istituto italiano d'arti grafiche, 1903.

Radcliffe, Anthony, and Nicholas Penny. Art of the Renaissance Bronze, 1500-1650. London: Philip Wilson, 2004.

Regio, Paolo. Vite dei sette santi protettori di Napoli. Naples: Giuseppe Cacchii, 1573; 1579.

Sallmann, Jean-Michel. Naples et ses saints à l'âge baroque (1540-1750). Paris: Presses Universitaires de France, 1994

. Santi barocchi: Modelli di santità, pratiche devozionali e comportamenti religiosi nel regno di Napoli dal 1540 al 1750. Translated by Carla Rabuffetti. Lecce: Argo, 1996.

Savarese, Silvana. Francesco Grimaldi e l'architettura della Controriforma a Napoli. Rome: Officina Edizioni, 1986.

. "Francesco Grimaldi e la transizione al Barocco. Una rilettura della Cappella del Tesoro nel Duomo di Napoli." In Barocco Napoletano, edited by Gaetana Cantone, 115-136. Rome: Istituto Poligrafico e Zecca dello Stato Libreria dello Stato, 1992.

Strazzullo, Franco. "La Corporazione napoletana dei fabbricatori, pipernieri e tagliamonti." Palladio 14, 1964.

. La Real Cappella del Tesoro di San Gennaro. Documenti inediti. Naples: Società Editrice Napoletana, 1978.

. La Cappella di San Gennaro nel Duomo di Napoli: document inediti. Naples: Istituto Grafico Editoriale Italiano, 1994.

Tutini, Camillo. Memorie della Vita Miracoli, e culto di San Gianuario martire Vescovo di Benevento, e principal protettore della Città di Napoli. Naples: Ottavio Beltrano, 1633.

Visceglia, Maria Antonietta. Identità sociale. La nobiltà napoletana nella prima età moderna. Milan: Edizioni Unicopli, 1998.

Walker Bynum, Caroline. Holy Feast and Holy Fast. Berkeley: University of California Press, 1988.

Wistreich, Richard. "Introduction. Musical material and cultural space." Renaissance Studies, 26, no. 1 (2012): 1-12.

Woodward, Ian. Understanding Material Culture. Los Angeles and London: Sage, 2007. 